\title{
Environmental attitude of junior high school students: Basis for proposed intervention
}

Actitud ambiental de los estudiantes de secundaria básica: base para la intervención propuesta

Atitude ambiental de alunos do ensino médio: bases para uma intervenção proposta

\author{
Jhester S. Hornejas \\ jhesterhornejas@gmail.com \\ Sta. Cruz National High School, Sta. Cruz Davao del Sur, Philippines \\ https://orcid.org/0000-0002-5792-0399
}

\begin{abstract}
The study was carried out to determine the significant difference of the environmental attitude of Junior High School students when analysed in terms of demographic profile. Non-experimental descriptive-survey research design was utilized using mean, t-test and analysis of variance (ANOVA) as the statistical tools in data treatment. The findings revealed a high extent of environmental attitude of students with a high extent of environmental awareness, attitude towards recovery, attitudes towards recycling and environmental consciousness and behaviour indicators. Furthermore, the study revealed no significant difference in the level of environmental attitude when analyzed by age and gender. However, there is significant difference in the year level. Hence, the null hypothesis pertaining to no significant difference of year level was rejected and these findings became the basis of the proposed intervention scheme.
\end{abstract}

Keywords: education, environmental attitude, junior high school students, intervention scheme, Philippines.

\section{RESUMO}

O estudo foi realizado para determinar a diferença significativa da atitude ambiental de alunos do ensino fundamental quando analisada em termos de perfil demográfico. O desenho de pesquisa descritiva não experimental foi utilizado usando média, teste t e análise de variância (ANOVA) como ferramentas estatísticas no tratamento de dados. Os resultados revelaram um elevado grau de atitude ambiental dos alunos com elevado grau de consciência ambiental, atitude em relação à recuperação, atitude em relação à reciclagem e consciência ambiental e indicadores de comportamento. Além disso, o estudo não revelou diferença significativa no nível de atitude ambiental quando analisado por idade e sexo. No entanto, há uma diferença significativa no nível do ano. Portanto, a hipótese nula referente a nenhuma diferença significativa no nível do ano foi rejeitada e esses resultados tornaram-se a base do esquema de intervenção proposto.

Palavras-chave: educação, atitude ambiental, alunos do ensino fundamental, intervenção esquema, Filipinas.

\section{RESUMEN}

El estudio se llevó a cabo para determinar la diferencia significativa de la actitud ambiental de los estudiantes de secundaria cuando se analiza en términos de perfil demográfico. Se utilizó un diseño de investigación de encuesta descriptiva no experimental utilizando la media, la prueba t y el análisis de varianza (ANOVA) como herramientas estadísticas en el tratamiento de datos. Los hallazgos revelaron un alto grado de actitud ambiental de los estudiantes con un alto grado de conciencia ambiental, actitud hacia la recuperación, actitudes hacia el reciclaje y conciencia ambiental e indicadores de comportamiento. Además, el estudio no reveló diferencias significativas en el nivel de actitud ambiental cuando se analizó por edad y género. Sin embargo, existe una diferencia significativa en el nivel del año. Por lo tanto, se rechazó la hipótesis nula relativa a la ausencia de una diferencia significativa de nivel anual y estos hallazgos se convirtieron en la base del esquema de intervención propuesto.

Palabras clave: educación, actitud ambiental, estudiantes de secundaria, intervención esquema, Filipinas. 


\section{INTRODUCTION}

Globally, people nowadays are actively engaging themselves to unfavorable environmental activities to individuals, corporate, constitutional and general stages (Ugulo \& Erkol 2013). Uzun and Saglam (2006) found out that individuals with thoughtless insolences to environmental problems have negative attitudes towards the issue which will cause continuous problems to the environment. In the Philippines, lawmakers created a law that would address the integration of environmental education in schools covering all levels. But this law has no proper implementation and action plans that will provide training and skilled people in environmental education that supports human development and participation in shaping a green vision (Medallon \& Gallardo, 2014).

Environmental quality is sometimes measured by the behavior of an individual and its environmental attitudes. These attitudes are composed of cognitive, affective and conative or behavioral elements that caused the increase or decrease in environmental quality. Preservation and utilization dimensions make a better environmental attitude while age, gender, urban-rural residence, socioeconomic status, nation, religion, politics, personality, values, experiences, education and environmental knowledge affects the rise and fall of pro-environmental attitudes (Gifford \& Reuven, 2012).

However, in the local setting, as observed by the Science Coordinator of a national high school in the south district, during the initial visit of the researcher, he stressed that there are several students regardless of their grade level, age and gender continuously engaging negative attitudes towards environment like throwing the garbage anywhere, mismanage solid waste even though they are taught environmental education as integral part in their school.

The researcher has not come across of a study that dealt on the level of environmental attitude of students as well as the significance difference on it when analyzed by demographic profile in the local setting. It is in this context that the researcher decided to conduct this study and put on record the environmental attitude of the students, particularly the junior high school students and what possible intervention can be proposed if the result of this study will reveal a negative or a low response in terms of concern on the environment.

\section{Research Objectives}

The main purpose of the study was to formulate an intervention program that will assess the environmental attitude of junior high school students of a national high school in the south district. Specifically, it sought to attain the following objectives:

1. To asess the level of environmental attitude of Junior High School students of a national in sounth district in terms of:

1.1 environmental awareness;

1.2 attitudes toward recovery;

1.3 attitudes toward recycling; and

1.4 environmental consciouness and behavior 
2. To determine the significance differene of the environmental attitude of students when analyzed interms of:

2.1 age;

2.2 gender; and

2.3 year level

3. To proposed intervention program based on the results of the study.

\section{Hypothesis}

The hypothesis in this study was tested at 0.05 level of significance.

1. There is no significant difference in the level of environmental attitude of Junior High School students in a national high school in the south district when analyzed in terms of its profile.

\section{THEORETICAL FOUNDATION}

This research study is anchored with the postulation of Birhanu (2013) which stated that participants from high grade level has better environmental attitude and participatory behavior and more environmentally knowledgeable than those lower grade teachers and learners. Further, grade eleven and twelve participants have better participatory behavior. Meanwhile, grade ten and twelve participants have higher level of environmental knowledge and attitude. Additionally, Ajzen's (1985) Theory of Planned Behavior which has been widely used as a framework for understanding influences on behavior and contends that intention to act is a key factor in predicting behavior. This intention is influenced affected by perception of social norms, perception of behavior control, and attitudes towards behavior (Wright, 2011). Gaining insight into these links is key if citizen science is to lead to the "attitudinal and behavioral" outcomes cited earlier in Cooper, Dickinson, Phillips, \& Bonney (2007).

Furthermore, this study is supported by the proposition of Schultz (2000) as he uses perspective - taking manipulation as an attempt for the activation of environmental concerns, and provided the proof that environmental concern is malleable across situation. As a matter of fact, the study shows that there will be a consistency of the role of extracurricular activities pertaining to student's attitude towards environment. It was suggested that whenever there are activities that boost student's engagement towards environment, there is a corresponding increase in environmental concerns. In addition, it emphasized the importance of environmental education as it provokes student's compassion and develops the sense of interconnectedness with environment.

\section{METHODS}

This portion contains the discussion on the method to be applied in this research study, namely; the research design, research locale, population and sample, research instruments, data collection, statistical tools, and ethical considerations of the study. 


\subsection{Research Design}

The researcher applied the descriptive method survey research for the study. An organized survey questionnaire was provided as an example to the respondents which gave knowledge and specific information. The researcher on the other hand, conducted an actual behavioral observation in order to provide a thorough record free from manipulation (Rofianto, 2011). Moreover, this is the most appropriate research design because the data on environment attitude of Junior High School students in a national high school in the south district are collected without discussion among the respondents.

\subsection{Respondents and Sampling}

The study utilized a random sampling technique consisting of 100 Junior High School students in a national high school in south district who are currently enrolled this SY 2017-2018. In this method, there is a possibility that each person in the sample of population could be selected as a subject (HadiRatham, Li, Abdulla, Diykh \& Wan, 2016). To give equal chances to the students who are enrolled on the said school, a list of all the names of the junior high school students for Grade 7, Grade 8, Grade 9 and Grade 10 was secured from the Guidance Office. The name of all the students representing the four grade levels were placed in four separate bowls and 25 names from each bowl was picked to represent the total sample size of 100 junior high school students. Further, only those junior high students (Grade 7, 8, 9 and 10) enrolled for SY 2017-2018 were included as samples for this study because they are the ones who can answer the questions in the survey and one of the primary respondents of the study.

Hence, those who do not belong to those classes for SY 2017-2018 were deemed excluded in the population. These are the students below Grade 7 because they do not yet have the capability of thoroughly comprehending the questions in the survey and may not be able to make a decisive response based on the scale. At any time, the respondents are free to withdraw from the participation of the survey if they feel that the questions being asked become detrimental on their part.

\subsection{Research Instrument}

A modified survey questionnaire was used in the gathering of data for this study. The questionnaire has two parts: Part 1 presented the profile of respondents in terms of age, year level and gender. Part 2 dealt with the questions about environmental attitude such as attitudes towards recycling, attitudes towards recovery, environmental consciousness and behavior, and environmental awareness. Also, a Likert scale of 1 to 5 is given for interpretation of the results wherein 5 represents Always, 4 for oftentimes, 3 for sometimes, 2 for seldom and 1 for never.

The modified questionnaire was submitted and validated for approval by the panel of expert validators. This was subjected to pilot testing/cronbach alpha to test the reliability of the question-items in the questionnaire. Besides, the result of the cronbach alpha is .793 which implied that items in the questionnaire were reliable. Presented below is the scale in choosing their answer. 


\section{Scale for the level of Environmental Attitude}

\section{Range of Means Descriptive Level Interpretation}
$4.20-5.00$
Very High
This means that the items in environmental attitude is always manifested.
$3.40-4.19$
High
This means that the environmental attitude is oftentimes manifested.
$2.60-3.39$
Moderate
This means that the environmental attitude is sometimes manifested.
$1.80-2.59$
Low
This means that the environmental is seldom manifested.
$1.00-1.79$
Very low
This means that the environmental attitude is never manifested.

\subsection{Data Gathering Procedure}

The researcher assured that all procedures in collecting data was properly followed during the conduct of the study. First, the adapted questionnaire was validated by the panel of expert to ensure that the different variables were free from any error.

The researcher wrote a letter of request to the Dean of the Professional Schools so that he can proceed with the conduct of the study. As soon as permission was granted, the researcher secured a letter of endorsement noted by the Dean of Professional Schools, addressed to the Principal of one of the public schools in a national high school in south district for easy access in the conduct of the study to the concerned students. Attachments were as follows: the information sheet about the proposed study, a student consent form and the two questionnaires. As soon as permission was granted by the principal, the researcher proceeded to the assigned teachers of the junior high school students for the distribution of the survey questionnaires to the identified 25 students each representing Grades 7, 8, 9 and 10. Thereafter, all survey questionnaires were collected and retrieved for statistical analysis after three days or a week. 
The researcher tabulated all the data to the Excel spread sheet and then, emailed it to the assigned statistician for statistical treatment. The statistician's interpretation of the collected data became the basis for the researcher for data analysis, discussion and recommendations in which the proposed intervention was drawn from the result of the survey. The study was conducted from December 2017-December 2018.

\subsection{Data Analysis}

The following tools were used in analyzing and interpreting the data.

Weighted Mean. This was used to know the level of environmental attitude of students in a national high school in south district.

T-test. This was applied to determine the significance difference of the level of environmental attitude when analyzed according to demographic profile.

Analysis of Variance (ANOVA).This was utilized to examine the significant mean difference when grouped according to, attitude towards recovery, environmental awareness, environmental consciousness and behavior, and attitude towards recycling and environmental consciousness and behavior.

\subsection{Ethical Consideration}

There are considerable ethical issues and concerns that have specific ramifications for this quantitative inquest. Such issues and concerns may arise primarily from the methodology involved in this study. The ethical contests that are pertinent to this research concern the issues of the right to conduct the study, confidentiality and anonymity.

The researcher observed and followed full ethical standards in the conduct of the study following the study protocol assessments and standardized criteria, particularly in managing the population and data such as, but not limited to:

Voluntary participations. The Grade 7, 8,9,10 students of the school were given the free-will to participate without any form of consequence or penalty or loss of benefits. Therefore, after the purpose and the benefits of the study will be described and presented to the participating school. Then, the rights of the respondents to contribute to the body of knowledge will be carefully considered and adhered upon.

Privacy and confidentiality. The researcher kept private and with utmost confidentiality the respondents' personal information that may be required in the study.

Informed consent process. The research questionnaires were free of technical terms that make it easier for the respondents to understand. It gives the respondents a clear view of the benefits they may get after the conduct of this study. The research questionnaire was administered with the consent of the school principal. 
Recruitment. The distribution of the respondents showed how the respondents were selected. Furthermore, the data collection procedures was indicated, as well as how the questionnaire was administered, and the manner of respondents involved in the study.

Risks. The study did not involve in high risks of situations that the respondents may experience in physical, psychological or socio-economic concerns. The study just involves in their field of motivation towards learning.

Benefits. The potential to yield generalizable knowledge about the participants' condition/ problem; nonmaterial compensation to participant (health education or other creative benefits)

Plagiarism. The study has no trace or evidence of misrepresentation of someone else's work as his own. The study undergone plagiarism detector using the Turnitin software.

Fabrication. The study has no trace or evidence of intentional misinterpretation of what has been done. No making up of data and results, or purposefully putting forward conclusions that are not accurate.

Falsification. The study has no trace of purposefully misrepresenting the work to fit a model or theoretical expectation and have no evidence of over claiming or exaggeration.

Conflict of Interest (COI). The study has no trace of conflict of interest like for example the disclosure of COI which is a group of conditions where professional judgment about the participants' welfare and legitimacy of the research should not be affected by a secondary interest like monetary or academic gains and recognitions.

Deceit. The study has no trace of misleading the respondents to any potential harm 


\section{RESULTS}

Presented in this chapter are the results, interpretation, and analysis of findings. Tables are arranged in the following order; level of environmental attitude of Junior High School students of a national high school in south district and the significant difference of the environmental attitude of students when analyzed in terms of age, gender and year level.

\subsection{Environmental Attitude of Junior High School Students}

The level of environment attitude of junior high school students of a national high school in the south district was computed and interpreted based on the obtained mean rating per indicator: Attitudes towards recovery, Environmental awareness, Environmental consciousness and behavior, and Attitudes towards recycling.

Shown in Table 1 is the level of environmental attitude of the students which pertains to the first problem of the study. The table reflected that the environmental attitudes of the students were high as indicated by the overall mean score of 3.90. It can be gleaned in the table that 2 indicators environmental consciousness and behavior and attitudes towards recovery gained the highest mean scores of 3.93 with a descriptive interpretation of High, respectively. It is followed by attitudes toward recycling with a mean score of 3.85 or high. And lastly, the indicator environmental awareness gaining a mean score of 3.83 descriptively interpreted as high.

Table 1

Level of Environmental Attitude of Junior High School Students

\begin{tabular}{|c|c|c|c|}
\hline Indicator & SD & Mean & $\begin{array}{l}\text { Descriptive } \\
\text { Levels }\end{array}$ \\
\hline Environmental Awareness & 0.46 & 3.83 & High \\
\hline Attitudes towards Recovery & 0.59 & 3.93 & High \\
\hline Attitudes towards Recycling & 0.59 & 3.85 & High \\
\hline $\begin{array}{l}\text { Environmental consciousness and } \\
\text { behavior }\end{array}$ & 0.54 & 3.93 & High \\
\hline OVERALL & 0.42 & 3.90 & High \\
\hline
\end{tabular}

\subsection{Significant Difference on the Level of Environmental Attitude of Junior High School Students when Analyzed by Age}

This presents the result of the alteration in the level of environmental attitude of Junior High School students was categorized by age, gender and grade level. 
The important difference in the level of environmental attitude of the Junior High School students of a national high school in south district analyzed by age was computed and analyzed through ANOVA as shown in Table 2, which answers to the second question of the study.

The overall environmental attitude of the junior high school students when analyzed by age revealed an F-value of 2.009 and a p-value of 0.140 which is greater than the 0.05 level of significance, leading to the failure in rejecting the null hypothesis. The indicators attitudes towards recovery, environmental awareness, environmental consciousness and behavior gained the F-value

\section{Table 2}

Significant Difference on the Level of Environmental Attitude of Junior High School Students when Analyzed by Age

\begin{tabular}{lll}
\hline Indicator & F-value & p-value \\
\hline Environmental awareness & 1.316 & .273 \\
Attitudes towards recovery & .703 & .498 \\
Attitudes towards recycling & 1.366 & .260 \\
Environmental consciousness and behaviour & 1.382 & .256 \\
Overall & $\mathbf{2 . 0 0 9}$ & $\mathbf{. 1 4 0}$ \\
\hline
\end{tabular}

$* P<0.05$

of $1.316,0.703,1.366$, and 1.382; and the p-value of $0.273,0.498,0.260,0.256$ respectively. These results revealed a no significant difference on the level of the environmental attitudes of the participants when analyzed by age, resulting to the failure in rejecting the null hypothesis.

\subsection{Significant Difference on the Level of Environmental Attitude of Junior High School Students when Analyzed by Gender}

Significant difference in the level of environmental attitude of junior high school students of a national high school in south district analyzed by Gender was computed and interpreted based on the T-test. The figures in Table 3 revealed that the environmental awareness of the students when analyzed by gender have no significant difference with an F-value of 1.703 and p-value of 0.195 . The indicators attitudes towards recovery and attitudes towards recycling revealed the F-value of 0.385 and 1.142 and the p-value of 0.536 and 0.288 respectively or no significant difference. Environmental consciousness and behavior revealed an F-value of 0.044 and p-value of 0.834 or no significant difference. The overall level of environmental attitude when analyzed by gender revealed an F-value of 0.019 and p-value of 0.319 , which is higher than the 0.05 level of significance. This means that there is no significant difference in the environmental attitudes of the students when analyzed by gender. Hence, the null hypothesis is accepted.

Table 3

Significant Difference on the Level of Environmental Attitude of Junior High School Students when Analyzed by Gender

\begin{tabular}{lll}
\hline Indicator & F-value & p-value \\
\hline Environmental awareness & 1.703 & 0.195
\end{tabular}




$\begin{array}{lll}\text { Attitudes towards recovery } & 0.385 & 0.536 \\ \text { Attitudes towards recycling } & 1.142 & 0.288 \\ \text { Environmental consciousness and behaviour } & 0.044 & 0.834 \\ \text { Overall } & 0.019 & 0.319\end{array}$

$* P<0.05$

\subsection{Significant Difference on the Level of Environmental Attitude of Junior High School Students when Analyzed by Year Level}

The significant difference in the level of environmental attitude of a national high school in south district when analyzed by year level was computed and interpreted based on the ANOVA test as shown in Table 4.

It can be gleaned on Table 4 that the overall level of environmental attitude of the junior high school students when analysed by year level gained an F-value of 3.692 and a p-value of 0.015 or significant. The indicators environmental awareness and environmental consciousness and behavior revealed the F-value of 1.695 and 1.254, and p-values of 0.174 and 0.295 respectively which denotes a no significant difference. However, the indicators attitudes towards recovery and attitudes towards recycling revealed F-values of 4.574 and 2.826, and p-values of 0.005 and 0.043 respectively, denoting a significant difference. These results revealed that the study has found enough evidence that there is a significant difference in the level of environmental attitudes of the junior high school students when analyzed by year level, hence the null hypothesis is rejected.

Table 4

Significant Difference on the Level of Environmental Attitude of Junior High School Students when Analyzed by Year Level

\begin{tabular}{lll}
\hline Indicator & F-value & p-value \\
\hline Environmental awareness & 1.695 & .174 \\
Attitudes towards recovery & 4.574 & .005 \\
Attitudes towards recycling & 2.826 & .043 \\
Environmental consciousness and behaviour & 1.254 & .295 \\
Overall & $\mathbf{3 . 6 9 2}$ & $\mathbf{. 0 1 5}$ \\
\hline
\end{tabular}

4.5 Post hoc Analysis on the Significant Difference in the Level of Attitudes towards Recovery, Attitudes towards Recycling and Environmental Attitude of Junior High School Students when Analyzed by Year Level

Post hoc analysis on the significant difference in the level of attitudes towards recovery, attitudes towards recycling, and environmental attitude of Junior High School students of a national high school in south district when analyzed by Year Level is presented in Table 5. It can be gleaned that the indicator attitudes towards recovery, the mean difference of 0.57880 of junior high school 
respondents who are in grade 7 and grade 9 attained a p-value of 0.001 or significant. Statistics revealed that there is sufficient ground to

\section{Table 5}

Post hoc Analysis on the Significant Difference in the Level of Attitudes towards Recovery, Attitudes towards Recycling, and Environmental Attitude of Junior High School students as a Whole when Analyzed by Year Level

\begin{tabular}{lclll}
\hline Indicator & Year Level & & $\begin{array}{l}\text { Mean } \\
\text { Difference }\end{array}$ & p-value \\
\hline $\begin{array}{l}\text { Attitudes } \\
\text { recovery }\end{array}$ & towards Grade 7 & Grade 9 & 0.57880 & 0.001 \\
\hline Attitudes & towards Grade 8 & Grade 9 & 0.41040 & 0.012 \\
recycling & Grade 10 & Grade 9 & 0.41175 & 0.026 \\
\hline \multirow{2}{*}{$\begin{array}{l}\text { Environmental } \\
\text { Attitude }\end{array}$} & Grade 7 & Grade 9 & 0.27920 & 0.016 \\
& Grade 8 & Grade 9 & 0.26880 & 0.020 \\
\hline
\end{tabular}

reject the null hypothesis. Thus, level of environmental attitudes of the junior high school students who are in grade 7 on attitudes on recovery is significantly higher that the students who are in grade 9. Attitudes towards recovery of the grade 9 and grade 10 students obtained a mean difference of 0.46678 with a p-value of 0.013 or significant difference. This means that the students who are in grade 9 have significantly higher level of environmental attitudes on attitudes towards recovery that those students who are in grade 10.

In terms of attitudes towards recycling, the 0.41040 mean difference of grade 8 and grade 9 students and the 0.41175 mean difference of grade 10 and grade 9 students revealed the p-values of 0.012 and 0.026 respectively, which is lower than the 0.05 level of significance. Statistics revealed that there is enough evidence to reject the null hypothesis. This means that the level of environmental attitudes of the grade 8 and grade 10 students of a national high school in south district in terms of attitudes towards recycling is significantly higher than those of the grade 9 students.

Further, the environmental attitude mean difference of 0.27920 of the grade 7 and grade 9 students revealed a p-value of 0.016 or significant, which means that the environmental attitude of the grade 7 students is significantly higher that the grade 9 students. The mean difference of 0.26880 of the grade 8 and grade 9 and the 0.38165 mean difference of grade 10 and grade 9 revealed the respective p-values of 0.020 and 0.004 , which are lower than the 0.05 level of significance. These mean that the environmental attitude of the grade 8 and grade 10 is significantly higher than the environmental attitude of the grade 9 students. Such results lead to the rejection of the null hypothesis of no significant difference in the level of environmental attitude of Junior High School students of a national high school in south district When Analyzed by Year Level.

\section{DISCUSSIONS}


Presented in this chapter are the discussions on the data gathered on the level of environmental attitude of Junior High School students in a national high school in south district and the significant difference of the environmental attitude of students when analyzed in terms of age, gender and year levels. The discussion starts on the indicators and followed by the significance of difference in the level of environmental attitude of students when analyzed in terms of age, gender and year level are thoroughly discussed.

\subsection{Environmental Attitude of Junior High School Students}

The high level of environmental attitude of the Junior High School students in a national high school in south district is based on the high ratings given by the respondents to the students' attitudes towards recovery and environmental consciousness and behaviour. The students in this school are showing their support in preserving the environment by always using rechargeable batteries instead of disposable batteries; recycle by using both sides of the paper, and using water wisely while brushing their teeth. These simple practices of the students in helping to preserve the environment is important as it is supported by various authors (Hornick et al.,1995; Mrema, 2008; Zelezny \& Schultz, 2000) who stated that recycling is more effective when compared to burning and burying, because it allows one to maximize the utilization of a resources; and with the right delivery of instructions, young students could encouraged to recycle more and help in the recovery of the environment. Further, the individuals' consciousness towards their environment helps in activating their engaging pro-environmental behaviors

\subsection{Significant Difference on the Level of Environmental Attitude of Junior High School Students When Analyzed by Age}

The overall result revealed a no significant difference on the level of environmental attitude of junior high school students of Santa Cruz High School when analyzed by age. This implies that environmental attitude of the students does not differ according to their age, that the students regardless of their age have the same level of environmental attitudes. The variance between the age groups revealed to have spread more widely within the age groups resulting to no significant difference on the level of environmental attitudes. Therefore, the null hypothesis is accepted.

The result of this study is in contrast to the study of Feleke ( 2010), Aminrad et al (2011), and Kebede (2010) which states that older respondents has a high level of promising attitudes compared to the younger ones. In fact in the study conducted by Birhanu (2013) where the participants were assessed through their age group, he found out that those in the age bracket of twenty-three and above has a high level of environmental knowledge, has the right attitude and are environment friendly individual. These types of people could be a catalyst in preventing and solving existing environmental problems.

Moreover, number of reports presented that adult or old aged people who participate in environmental activities always out-smarted younger participants (Bogner and Britta, 2010). Further, Sidique et al (2010) has strengthened this by stressing that the reduction of waste is due to the efforts of those recyclers who are more familiar with the drop-off sites and those who have more time to do the recycling activity.

On the other hand, Yilmaz et al (2004) argue that younger generations are more knowledgeable about the environment and other environmental issues leading them to have higher 
understanding, positive attitude, and behavior towards environmental issues than the older generations. These authors have already proven that older people are wiser in dealing with the environmental problems when compared to the younger ones because they have more experience and consciousness when it comes to environmental issues. Sanchez and Lafuente (2010) stated that the main triggers of an individual's attitude of pro-environmental values and views are the individual's awareness of the environmental behaviour and consciousness.

\subsection{Significant Difference on the Level of Environmental Attitude of Junior High School When Analyzed by Gender}

The overall result revealed that there is no significant difference on the level of environmental attitude of junior high school students of Santa Cruz High School when analyzed by gender. This implies that whether the student is a male or a female, the environmental attitude of the student sustained a high level. Therefore, the null hypothesis is accepted.

In terms of environmental attitude and participatory behavior, the result of the study is supported and has similarities with that of Feleke (2010) and Kebede (2010) that gender cannot affect the participatory behavior and environmental attitude of students. This is also the stand of Pilgrim et al, 2007, that eco-literacy among males and females are the same which states that there is no difference in eco-literacy levels among males and females.

Meanwhile, Birhanu (2013) cited in his study that between males and females, males have higher level of environmental knowledge. Both sexes are alike in attitude and participatory behavior towards the environmental difficulties, consequences, causes, problems, and solutions to land degradation. Regardless of gender, Kuppuraji and Koldliwad (2012) stated that enhancing the environmental awareness will connect the individual behaviour towards the environment with the requirements of preventing environmental degradation.

However, Ewen et al (2015) has a different view regarding gender role in the environment. According to him, women shows greater concern and more responsible for nature and environment than men. This is an example of ecofeminism discourse where feminist theory and biology met and was combined. If this discourse is proven scientifically, then schools should appoint female teachers to teach about the environment since they could put more effort in teaching environmentalism and sustainable development compared to male teachers. It is in this way that the study can be verified or not.

\subsection{Significant Difference on the Level of Environmental Attitude of Junior High School Students When Analyzed by Year Level}

The overall result revealed a significant difference on the level of environmental attitude of junior high school students of Santa Cruz High School when analyzed by year level. The variance between the year level groups revealed to be more concentrated within the year level groups resulting to a significant difference on the level of environmental attitude of the participants. This implies that the students' environmental attitude is influenced by the category of which year level they belong with. This means that the students' environmental attitude differs with regards to their year level. Thus, the null hypothesis is rejected.

In the study conducted by Birhanu (2013), results presented that grade 11 and 12 participants have better participatory behavior. Meanwhile, grade 10 and 12 participants have higher level of environmental knowledge and attitude. It is then concluded that teachers from the high-grade level has the higher amount of knowledge about the environment and better 
understanding about the issues. They also have a better environmental attitude and participatory behavior compared to those lower grade level teachers.

In his study Yilmaz et al (2004) argued stating that educational status of students does not affect its environmental awareness of the university students from age range of 18 to 22 have the same awareness regarding the environment. However, it was later opposed by the study conducted by Aminrad et al (2010) which suggests that as the participants' grade level increases, their environmental awareness also increases. Additionally, this is because of the exposure they get as their grade level increases. They are exposed to broader environment and issues which test their mental capability which will later give ways in developing their senses and behaviors especially towards environment.

\section{CONCLUSIONS}

With considerations on the findings of the study, conclusions are drawn in this section. First, there is a high level of environmental attitude of Junior High School students of a national high school in the south district in terms of attitudes towards recovery, environmental awareness, environmental consciousness and behavior, and attitudes towards recycling. Second, there is no significant difference in the environmental attitude of students when analyzed in terms of age and gender; however, there is significant difference in the environmental attitude of students when analyzed in terms of year level. Third, in the light of the findings of the study, an intervention scheme is formulated for the contingency of the practice of environmental awareness, attitudes towards recovery, attitudes towards recycling, and the environmental consciousness and behaviour with 3.90 as the base mean for the intervention. Lastly, the results of the study signifies that the individuals intention to act upon the environmental issues predict their environmental attitudes, which confirms the anchor theory of the study.

Morover, only those junior high students (Grade 7, 8, 9 and 10) enrolled for SY 2017-2018 were included as samples for this study because they are the ones who can answer the questions in the survey and one of the primary respondents of the study. Hence, those who do not belong to those classes for SY 2017-2018 were deemed excluded in the population. These are the students below Grade 7 because they do not yet have the capability of thoroughly comprehending the questions in the survey and may not be able to make a decisive response based on the scale. At any time, the respondents are free to withdraw from the participation of the survey if they feel that the questions being asked become detrimental on their part.

Besides the results of the study can be a great help to all the people, young and old, rich and poor, as the findings of the study may be an inspiration to all to be sensitive and create a proactive attitude towards environment. Finally, data to be acquired from this study can be used by future researchers as their springboard to guide them in conducting similar studies.

\section{RECOMMENDATION}

The researcher came up with the following recommendations based on the results of the study that will serve as an intervention program in designing and maintaining sustainability of the programs and activities concerning attitudes towards recovery, environmental awareness, environmental consciousness and behavior, and attitudes towards recycling among students. In particular, the researcher has the following recommendation: As to environment awareness, the conduct of symposia for environmental awareness intensifying the significance of biodiversity in the ecosystem; disseminate information by showing some visuals and documentaries about the 
environment such as "An Inconvenient Truth" and "Planet Earth", organizing a tree-planting activity in school and nearby areas with short introduction about the vital role of trees in promoting a healthy and sustainable earth, and encourage the students to recycling by conducting a recycling workshop. Organize an Earth Day Awareness rally or Earth Day fair with speakers from different environmental groups. Further, with the result of the study, the school administration may implement a continuous improvement to facilitate attitude towards recycling. The activities may include training of students on the conservation of energy by way of consumption of the basic resources, conserving and reduce buying unnecessary things, practicing garbage segregation, and training students' awareness on recyclable products. On the area of attitude, the environmental responsiveness and reprocessing and environmental consciousness and behavior, the school administration may facilitate the conduct of TV shows and program to give full opportunity for the students to advocate environmental concerns to all people, not only in school but also in the community.

\section{PROPOSED INTERVENTION SCHEME FOR THE ENVIRONMENTAL ATTITUDES OF JUNIOR HIGH STUDENTS IN NATIONAL HIGH SCHOOL SOUTH DISTRICT}

\subsection{RATIONALE}

An intervention scheme is a collected strategies desire to improve the Environmental attitude of Junior High Students of a national high school south district. These intervention may include recognizing various activities in the implementation of the environmental attitude of students .Intervention that include different activities that are usually the most effective ways in attaining proactive attitude towards environment.

This action plan focuses on the environmental attitude of students that with high level of results, giving emphasis on the lower mean result on environmental consciousness and behaviour as an indicator. These areas are paramount to further improve the environmental attitude of students.

The result of the study on the environmental attitude of Junior High School students is highly extensive in terms of environmental consciousness and behaviour. The researcher found out that there is still a need to improve and enhance the consciousness and behaviour of students towards environment through augmenting activities where their consciousness may involve.

\subsection{INTERVENTION SCHEME DESCRIPTION}

The intervention scheme is design to help the school administration as their base line studies for enhancing and improving Junior High School students' consciousness and behaviour towards the environment of a national high school south district. The scheme contains theme, objectives, activities, personal involved, budget, time frame and expected results.

\subsection{OBJECTIVES}

This intervention scheme will seek to fulfil the following objectives:

1. To intensify the significance of biodiversity in the ecosystem among the Junior High School students and all other stakeholders;

2. To minimize electrical bills/water bills by saving energy in the environment;

3. To know the contemporary issues in the environment thru an interview with community folks; 
4. To utilize recyclable materials as their props and costumes.

\subsection{TARGET BENEFICIARIES}

The target beneficiaries of this proposed intervention scheme are the following:

1. School administrator

2. Teachers

3. Students

4. Local Government officials (LGU)

\subsection{IMPLEMENTATION}

The implementation guideline for the intervention scheme is to present the findings to the Schools Division Superintendent for recommendation and approval by the School Head. Approved recommendation is then subject for the preparation of Program of Works for budget purposes. Further, the release of allotment of subsidy and cash will be allocated to respected school, the national high school south district in order for the implantation of the activity will be completed.

Hence, the success indicators of the implementing guideline will include the following: total awareness of the students about environmental concerns and application of various coping mechanisms for the preservation of biodiversity, continuous development and training of students on the conservation of energy, full opportunity for the students to air/advocate environmental matters with their peers and people in the community and development of students' ability to be more creative in the utilization of recyclable materials as their props and costumes.

\subsection{MONITORING AND EVALUATION}

Monitoring and evaluation will be done after executing the strategies developed in this program to ensure a quality output. The school division of Davao del Sur will create an inspectorate team to check whether the implementation meet the required standard base on design and specification. An evaluation survey will be conducted to concerned students for better satisfaction and future enhancement after the feedback revealed. Reports on the monitoring and evaluation results shall be rightfully documented and submit to the school administrator through the division's superintendent for the making of some corrective actions if necessary, to achieve common goals.

\section{REFERENCES}

Ajzen, I. (1985). From intentions to actions: A theory of planned behavior. In J. Kuhl\& J. Beckmann (Eds.), Actioncontrol: From cognition to behaviour, pg. 11-39. Retrieved from https:// www.scirp.org/(S(143dyn45teexjx55qlt3d2q))/reference/ReferencesPapers.aspx?ReferenceID=718488

Aminrad, Z., Zakaria, S.Z.S., Hadi, S. \&Sakari, M. (2012).Relationship between awareness, knowledge and attitudes towards environmental education among secondary school students in Malaysia. World Applied Sciences Journal, 22 (9), 1326-1333.

Birhanu, A. (2013). Factors influencing environmental knowledge, attitude and participatory behavior towards land degradation.the case of Injibara secondary and preparatory school, north-western Ethiopia. Science, Technology and Arts Research Journal, 2(2), 140-147. Retrieved from https://search.proquest.com/docview/1532504686?accountid=31259

Bogner, F. and Britta, O. (2010).Gender, age and subject matter: impact on teachers' ecological values. Environmentalist, (2), 111-122. 
Cooper, C. B., Dickinson, J., Phillips, T., \&Bonney, R. (2007).Citizen science as a tool for conservation in residential ecosystems.Ecology and Society, 12(2), 11.

Ewen, B. M. C., Clément, P., Gericke, N. M., Nyberg, E., Hagman, M., \&Landström, J. (2015). Female and male teachers' pro-environmental behaviour, conceptions and attitudes towards nature and the environment do not differ: Ecofeminism put to the test. Asia - Pacific Forum on Science Learning and Teaching, 16(1), 1-30. Retrieved from https://search.proquest.com/docview/1955993025?accountid=31259

Feleke, E. (2010). Students' awareness, attitude and intension towards urban environmental problems in selected preparatory schools of Addis Ababa (Unpublished M.A Thesis) Addis Ababa University.

Gifford, R., \&Reuven, S. (2012).The Oxford Handbook of Environmental and Conservation Psychology.Psychology, Social Psychology: Online Publication. DOI: 10.1093/oxfordhb/9780199733026.013.0004.

HadiRatham, A. G., Li, Y., Abdulla, S., Diykh, M., \& Wan, X. (2016).Classification of epileptic EEG signals based on simple random sampling and sequential feature selection.Brain Informatics, 3(2), 85-91. doi:http://dx.doi.org/10.1007/s40708016-0039-1

Hornik, J., Cherian, J., Madansky, M., \&Narayana, C. (1995). Determinants of recycling behavior: A synthesis of research results. The Journal of Socio-Economics, 24(1), 105-127. http://dx.doi.org/10.1016/10535357(95)90032-2

Medallon M. \& Gallardo M. (2014). Environmental awareness campaign: That change it brings. Asia Pacific Journal of Multidisciplinary Research,2(1), 115.

Pilgrim, S., Smith, D., Pretty, J. (2007). Across-regional assessment of the factors affecting eco-literacy: Implications for Policy and Practice. Ecological Applications, 17(6), 1742-1751.

Rofianto, W. (2011).Exploratory research design.Retrieved from https://rofianto.files.Wordpress.com/2011/04/mr_02.pdf.

Sidique, S.F., Lupi, F., \& Joshi, S.V. (2010).The effects of behavior and attitudes on drop-off recycling activities.Resources, Conservation and Recycling, 54(3), 163-170.

Sanchez, M.J. \&Lafuente, R. (2010). Defining and measuring environmental consciousness. Revista International de Sociología (RIS), 68(3), 731-755.

Schultz, P. W. (2000). Assessing the structure of environmental concern: Concern for self, other people, and the biosphere.Empathizing with nature: The effects of perspective taking on concern for environmental Issues.Journal of Social Issues, 56(3), 391-406.

Ugulu, I., Sahin, M., \&Baslar, S. (2013). High school students' environmental attitude:Scale development and validation. International Journal of Educational Sciences, 415-424.

Uzun, N., \&Saglam, N. (2006).Environmental Attitude Scale Development and Validation for Secondary School Students.Journal of Hacettepe University Faculty of Education, 240-250.

Wright, D. (2011). Evaluating a citizen science research programme: Understanding the people who make it possible (Unpublished master's thesis). Department of Zoology, University of Cape Town: Cape Town, South Africa.

Yilmaz, O., Boone, W.J. \& Andersen, H.O. (2004). Views of elementary \& middle school Turkish students toward environmental issues.International Journal of Science Education,(12), 1527-1546. 